\title{
Uji Berbagai Media Tanam Dalam Meningkatkan Pertumbuhan Bibit Anggrek Bulan Yang Berasal Dari Alam
}

\author{
Syarif Nizar Kartana \\ email : syarifnizarkartana@yahoo.com
}

\begin{abstract}
Abstrak: Penelitian ini bertujuan untuk mengetahui media tanam yang paling sesuai untuk meningkatkan pertumbuhan bibit anggrek bulan yang berasal dari alam. Penelitian ini dilaksanakan di Jalan Pangeran Kuning, Kelurahan Tanjungpuri, Kecamatan Sintang, Kabupaten Sintang, mulai dari bulan Oktober 2016 sampai Februari 2017. Hasil penelitian menunjukkan bahwa penggunaan media moss atau lumut memberikan pertumbuhan yang terbaik yaitu meningkatkan jumlah akar sebanyak 4,29 buah dan meningkatkan tinggi tanaman sebesar $3,86 \mathrm{~cm}$.
\end{abstract}

Kata kunci : Uji, Media tanam, bibit anggrek bulan alam

\section{PENDAHULUAN}

\section{Latar Belakang}

Anggrek Bulan (Phalaenopsis sp) adalah salah satu bunga nasional Indonesia yang memiliki kepopuleran dan keindahan yang eksotis sehingga membuatnya banyak diburu yang pada akhirnya membuat keberadaannya di alam bebas terancam kepunahan terutama di daerah Sintang. Kepopuleran anggrek jenis Phalaenopsis $s p$ bukan hanya di kalangan pecintanya, melainkan di kalangan pemula bahkan orang awam sekalipun. Pesona yang dihadirkan oleh sosok bunganya yang beragam warna, bentuk, corak, dan aroma khas pada setiap jenisnya mampu memberikan inspirasi bagi para penyilang untuk melahirkan hibrida-hibrida baru demi pertimbangan selera pasar dan kepuasan berkreasi bagi penyilangnya.

Usaha yang dapat dilakukan untuk mengatasi kepunahan anggrek bulan di alam bebas adalah dengan mengembangkannya di luar habitat asli atau secara ex situ. Salah satu faktor penting dalam pengembangan anggrek bulan di luar habitatnya adalah pemilihan jenis media yang sesuai untuk mendukung pertumbuhannya. Media untuk pemindahan anggrek harus disesuaikan dengan jenis anggrek, iklim dan ketersediaannya. Beberapa bahan yang dapat digunakan sebagai media tanam anggrek adalah pakis, sabut kelapa, arang, lumut dan beberapa bahan organik lainnya (Hendaryono, 1998). Berbagai jenis media yang dapat digunakan sebagai media tanam dapat diperoleh dengan mudah khususnya di Kabupaten Sintang, tetapi belum tentu sesuai sebagai media tanam anggrek bulan.

Peneltian ini bertujuan untuk mengetahui media tanam yang paling sesuai untuk meningkatkan pertumbuhan bibit anggrek bulan yang berasal dari alam. 


\section{METODOLOGI PENELITIAN}

\section{Tempat dan Waktu Penelitian}

Penelitian ini dilaksanakan di Jalan Pangeran Kuning, Kelurahan Tanjungpuri, Kecamatan Sintang, Kabupaten Sintang, mulai dari bulan Oktober 2016 sampai Februari 2017.

\section{Rancangan Percobaan}

Rancangan penelitian yang digunakan dalam penelitian ini adalah Rancangan Acak Kelompok dengan penggunaan 4 jenis media tanam dimana setiap perlakuan diulang sebanyak 7 kali. Perlakuan dalam penelitian ini adalah sebagai berikut :

$\mathrm{m}_{1}=$ media arang tempurung kelapa

$\mathrm{m}_{2}=$ media moss

$\mathrm{m}_{3}=$ media akar kadaka (Asplenium nidus)

$\mathrm{m}_{4}=$ media sabut kelapa

\section{Bahan Dan Alat Penelitian}

Bahan dalam penelitian ini adalah : bibit anggrek bulan yang berasal dari hutan Jembelak, Kecamatan Sintang, pot plastik, media tanam yang terdiri dari arang tempurung kelapa; moss atau lumut; akar kadaka; dan sabut kelapa. Alat yang digunakan dalam penelitian ini adalah papan, meteran, handsprayer, kamera, dan alat tulis menulis.

\section{Pelaksanaan Penelitian}

Rangkaian kegiatan dalam penelitian ini adalah : penyiapan media tanam, penyiapan tempat penelitian, penyiapan bibit anggrek bulan, penanaman bibit anggrek bulan, pemeliharaan yang meliputi penyiraman dan pemupukan.

\section{Pengumpulan Data}

Data yang diamati dalam penelitian ini adalah pertambahan jumlah akar dan pertambahan tinggi tanaman.

\section{Analisis Data}

Data yang diperoleh selanjutnya akan dianalisis dengan Analisa Sidik Ragam, apabila terdapat pengaruh maka dilanjutkan dengan Uji Beda Nyata Jujur dengan tingkat kepercayaan 95\% sampai 99\% (Gaspers,1999). 


\section{HASIL DAN PEMBAHASAN}

\section{Hasil Penelitian}

\section{Pertambahan Jumlah Akar}

Rata-rata hasil pengamatan pertambahan jumlah akar tanaman dapat dilihat pada Tabel 1 berikut.

Tabel 1. Data pertambahan jumlah akar anggrek bulan (buah)

\begin{tabular}{cccccccccc}
\hline \multirow{2}{*}{ Perlakuan } & I & II & III & IV & V & VI & VII & \multirow{2}{*}{ Jumlah } & \multirow{2}{*}{ Rerata } \\
\cline { 2 - 8 } & 1,00 & 2,00 & 1,00 & 3,50 & 2,00 & 2,00 & 2,50 & 14,00 & 2,00 \\
$\mathrm{~m}_{1}$ & 8,00 & 8,00 & 2,50 & 4,50 & 3,50 & 2,00 & 1,50 & 30,00 & 4,29 \\
$\mathrm{~m}_{2}$ & 1,00 & 2,00 & 3,50 & 1,50 & 2,50 & 3,00 & 3,00 & 16,50 & 2,36 \\
$\mathrm{~m}_{3}$ & 3,00 & 3,00 & 3,00 & 1,50 & 1,00 & 4,00 & 2,60 & 18,10 & 2,59 \\
$\mathrm{~m}_{4}$ & $\mathbf{1 3 , 0 0}$ & $\mathbf{1 5 , 0 0}$ & $\mathbf{1 0 , 0 0}$ & $\mathbf{1 1 , 0 0}$ & $\mathbf{9 , 0 0}$ & $\mathbf{1 1 , 0 0}$ & $\mathbf{9 , 6 0}$ & $\mathbf{7 8 , 6 0}$ & $\mathbf{2 , 8 1}$ \\
\hline Total & $\mathbf{1 0}$
\end{tabular}

Sumber : Hasil pengamatan

Data hasil pengamatan tersebut menggunakan Analisa Sidik Ragam selanjutnya dianalisa dengan yang disajikan pada Tabel 2 berikut.

Tabel 2. Analisa Sidik Ragam pengaruh penggunaan media terhadap pertambahan jumlah akar anggrek bulan (buah)

\begin{tabular}{lcccccc}
\hline \multirow{2}{*}{$\begin{array}{c}\text { Sumber } \\
\text { Keragaman }\end{array}$} & $\begin{array}{c}\text { Derajat } \\
\text { Bebas }\end{array}$ & $\begin{array}{c}\text { Jumlah } \\
\text { Kuadrat }\end{array}$ & $\begin{array}{c}\text { Kuadrat } \\
\text { Tengah }\end{array}$ & F-Hit & \multicolumn{2}{c}{ F-Tab } \\
\hline Ulangan & 6 & 6,65 & 0,95 & 0,50 & 3,66 & 4,01 \\
Perlakuan & 3 & 21,62 & 5,41 & $2,84 * *$ & 2,93 & 4,58 \\
Galat & 18 & 53,35 & 1,91 & & & \\
\hline Total & $\mathbf{2 7}$ & $\mathbf{8 1 , 6 2}$ & & kk $=$ & $\mathbf{4 9 , 1 7}$ & \\
\hline
\end{tabular}

Sumber : Hasil analisa data

Keterangan $\quad: * *=$ Berpengaruh pada selang kepercayaan $99 \%$

Hasil Analisa Sidik Ragam menunjukkan bahwa penggunaan media tanam berpengaruh terhadap pertambahan jumlah akar tanaman anggrek bulan sehingga dilanjutkan dengan Uji BNJ. Hasil Uji BNJ ditampilkan pada Tabel 4 berikut. 
Tabel 4. Uji BNJ pengaruh penggunaan berbagai media tanam terhadap pertambahan jumlah akar tanaman anggrek bulan (buah)

\begin{tabular}{|c|c|c|c|c|}
\hline Perlakuan & Rerata & & Beda & \\
\hline $\mathrm{m}_{1}$ & $2,00 \mathrm{a}$ & - & & \\
\hline $\mathrm{m}_{3}$ & $2,36 \mathrm{a}$ & $0,36^{\mathrm{ns}}$ & - & \\
\hline $\mathrm{m}_{4}$ & $2,59 \mathrm{a}$ & $0,59^{\mathrm{ns}}$ & $0,23^{\mathrm{ns}}$ & - \\
\hline \multirow[t]{2}{*}{$\mathrm{m}_{2}$} & $4,29 \mathrm{~b}$ & $2,29 * *$ & $1,93 * *$ & $1,70 * *$ \\
\hline & sy $=$ & 0,20 & & \\
\hline Q0.05 = & 3,61 & & BNJ $0.05=$ & 0,71 \\
\hline Q0.01 = & 4,70 & & BNJ $0.01=$ & 0,93 \\
\hline
\end{tabular}

Keterangan : angka yang ditandai huruf yang sama tidak berbeda nyata

Hasil Uji BNJ menunjakkan bahwa penggunaan media tanam moss atau lumut adalah media tanam terbaik dalam meningkatkan pertambahan jumlah akar tanaman anggrek bulan yaitu sebanyak 4,29 buah.

\section{Pertambahan Tinggi Tanaman}

Rata-rata hasil pengamtan pertambahan tinggi tanaman dapat dilihat Tabel 5 berikut.

Tabel 5. Data pertambahan tinggi tanaman anggrek bulan $(\mathrm{cm})$

\begin{tabular}{cccccccccc}
\hline \multirow{2}{*}{ Perlakuan } & \multicolumn{7}{c}{ Ulangan } & \multirow{2}{*}{ Jumlah } & \multirow{2}{*}{ Rerata } \\
\cline { 2 - 7 } & I & II & III & IV & V & VI & VII & & \\
\hline $\mathrm{m}_{1}$ & 2,00 & 3,50 & 1,00 & 1,00 & 2,00 & 3,00 & 1,00 & 13,50 & 1,93 \\
$\mathrm{~m}_{2}$ & 7,00 & 4,00 & 2,00 & 5,00 & 3,00 & 3,50 & 2,50 & 27,00 & 3,86 \\
$\mathrm{~m}_{3}$ & 3,00 & 2,50 & 2,50 & 2,50 & 2,50 & 5,00 & 4,50 & 22,50 & 3,21 \\
$\mathrm{~m}_{4}$ & 2,00 & 3,50 & 2,50 & 2,50 & 3,00 & 2,50 & 1,50 & 17,50 & 2,50 \\
\hline Total & $\mathbf{1 4 , 0 0}$ & $\mathbf{1 3 , 5 0}$ & $\mathbf{8 , 0 0}$ & $\mathbf{1 1 , 0 0}$ & $\mathbf{1 0 , 5 0}$ & $\mathbf{1 4 , 0 0}$ & $\mathbf{9 , 5 0}$ & $\mathbf{8 0 , 5 0}$ & $\mathbf{2 , 8 8}$ \\
\hline
\end{tabular}

Sumber : Hasil pengamatan

Data hasil pengamatan tersebut selanjutnya dianalisis dengan Analisa
Sidik Ragam yang disajikan pada Tabel 6 berikut. 
Tabel 6. Analisa Sidik Ragam pengaruh penggunaan media tanam terhadap pertambahan tinggi tanaman anggrek bulan $(\mathrm{cm})$

\begin{tabular}{lcccccc}
\hline \multirow{2}{*}{$\begin{array}{c}\text { Sumber } \\
\text { Keragaman }\end{array}$} & $\begin{array}{c}\text { Derajat } \\
\text { Bebas }\end{array}$ & $\begin{array}{c}\text { Jumlah } \\
\text { Kuadrat }\end{array}$ & $\begin{array}{c}\text { Kuadrat } \\
\text { Tengah }\end{array}$ & F-Hit & \multicolumn{2}{c}{ F-Tab } \\
\hline Ulangan & 6 & 8,50 & 1,21 & 1,39 & 3,66 & 4,01 \\
Perlakuan & 3 & 14,81 & 3,70 & $4,23^{* *}$ & 2,93 & 4,58 \\
Galat & 18 & 24,50 & 0,88 & & & \\
\hline Total & $\mathbf{2 7}$ & $\mathbf{4 7 , 8 1}$ & & kk $=$ & $\mathbf{3 2 , 5 4}$ & \\
\hline
\end{tabular}

Sumber : Hasil analisa data

Keterangan $\quad: * *=$ Berpengaruh pada selang kepercayaan $99 \%$

Hasil Analisa Sidik Ragam bulan sehingga dilanjutkan dengan Uji menunjukkan bahwa penggunaan media tanam berpengaruh terhadap BNJ. Hasil Uji BNJ ditampilkan pada pertambahan tinggi tanaman anggrek

Tabel 7. Uji BNJ pengaruh penggunaan media tanam terhadap pertambahan tinggi tanaman anggrek bulan $(\mathrm{cm})$

\begin{tabular}{|c|c|c|c|c|}
\hline Perlakuan & Rerata & & Beda & \\
\hline $\mathrm{m}_{1}$ & $1,93 \mathrm{a}$ & - & & \\
\hline $\mathrm{m}_{4}$ & $2,50 \mathrm{~b}$ & $0,57 *$ & - & \\
\hline $\mathrm{m}_{3}$ & $3,21 \mathrm{c}$ & $1,29 * *$ & $0,71 * *$ & - \\
\hline \multirow[t]{2}{*}{$\mathrm{m}_{2}$} & $3,86 \mathrm{~d}$ & $1,93 * *$ & $1,36 * *$ & $0,65 * *$ \\
\hline & sy $=$ & 0,13 & & \\
\hline Q0.05 = & 3,61 & & BNJ $0.05=$ & 0,48 \\
\hline Q0.01 = & 4,70 & & BNJ 0.01 = & 0,63 \\
\hline
\end{tabular}

Keterangan : angka yang ditandai huruf yang sama tidak berbeda nyata

Hasil Uji BNJ menunjukkan bahwa penggunaan media tanam moss atau lumut dapat meningkatkan pertambahan tinggi tanaman lebih baik daripada media tanam yang lainnya yaitu sebesar $3,86 \mathrm{~cm}$.

\section{Pembahasan}

Menurut Sutater (1996) dan Sutiyoso (1996) media tumbuh yang baik bagi pertumbuhan anggrek harus memenuhi beberapa persyaratan, antara lain: daya tahan lapuk yang berimbang, tidak menjadi sumber penyakit atau mengandung bahan toksik, remah untuk pertumbuhan akar, aerasi dan drainase yang baik, mampu mengikat air dan memiliki kandungan hara yang mencukupi, ringan, bersahabat dengan lingkungan, murah dan relatif mudah 
didapat dalam jumlah yang diinginkan.

Ditambahkan oleh Don WS., dkk (2001) anggrek bulan menghendaki media yang tidak cepat lapuk, mudah ditempel oleh akar, memiliki rongga atau porous untuk sirkulasi udara, dapat menyimpan zat hara dan tidak mudah menjadi sumber penyakit.

Hasil penelitian menunjukkan bahwa penggunaan media tanam moss atau lumut memberikan pertumbuhan yang paling baik untuk bibit anggrek bulan yang berasal dari alam dibandingkan dengan media yang lainnya. Hal ini disebabkan karena media moss atau lumut memiliki beberapa kelebihan dibandingkan dengan media yang lainnya. Menurut Anonim (2014) akar anggrek yang menggunakan media moss lebih cepat tumbuh dan lebih jarang busuk dan berwarna putih mulus. Seratnya agak kasar dan panjang - panjang, mampu menyimpan air dengan baik tetapi tidak menyebabkan media terlalu basah karena draenasenya termasuk bagus. Pori - porinya yang besar menyebabkan akar anggrek bulan yang tergolong agak besar akan mudah berkembang dengan baik.

\section{KESIMPULAN DAN SARAN}

Hasil penelitian menunjukkan bahwa penggunaan media moss atau lumut merupakan media tanam yang paling sesuai untuk meningkatkan pertumbuhan bibit anggrek bulan yang berasal dari alam dimana dapat meningkatkan pertambahan jumlah akar sebanyak 4,29 buah dan tinggi tanaman sebesar 3,86 cm. Penggunaan moss atau lumut dapat digunakan untuk media tanam anggrek bulan yang berasal dari alam.

\section{DAFTAR PUSTAKA}

Anonim. 2014. Sphagnum moss media tanam untuk anggrek. Kebun bibitkoe.blogspot.com.

Brian dan Wilma. R., 1987. Anggrek Sebagai Tanaman Hias di Dalam Rumah. Bamdung. Pioner Jaya.

Don WS, Trees E dan Cheery H. 2001. Cara Merawat dan Menanam Anggrek Bulan. Jakarta. Gramedia Pustaka Utama.

Gaspers, V. 1999. Metode Perancangan Percobaan, Armico. Bandung.

Hendaryono D. PS. 1998. Budidaya Anggrek Dengan Bibit Dalam Botol. Yogyakarta. Kanisius.

Rizal Djafareer. 2003. Phalaenopsis Spesies ; Jenis Dan Potensi Untuk Silangan. Jakarta. Penebar Swadaya.

Semiarti, E. 2003. Pendekatan Genetika Molekuler Terhadap Pertumbuhan Meristem Ujung 
Batang Pada Tanaman Anggrek. Laporan Research Grant. Laboratorium Kultur Jaringan Tumbuhan Fakultas Biologi. Universitas Gadjah Mada. Yogyakarta. Hal. 1-4.

Surabaya Orchid Show. 2003. Anggrek Produk Unggulan Menyongsong AFTA. Makalah Seminar Angrek. WTC 24-28 April 2003. Surabaya.
Sutater. T. 1996. Pengembangan Teknologi Budidaya Menuju Usaha Tani Anggrek Berciri Industri. Makalah Seminar Anggrek. Jakarta. Perhimpunan Anggrek Indonesia (PAI).

Sutiyoso. Y. 1996. Pengaruh Media Terhadap Pertumbuhan Dan Pembungaan Tanaman Anggrek. Makalah Seminar Anggrek. Jakarta. Perhimpunan Anggrek Indonesia (PAI). 